\title{
KOMLÓSI ISTVÁN
}

\section{A DEBRECENI AGRÁRFELSŐOKTATÁS ELSŐ 150 ÉVE}

\begin{abstract}
The first 150 years of Agricultural Tertiary EDUCATION in DebreCen. The Georgikon in Keszthely was founded in 1797 as the first one in the line of subsequent agricultural tertiary institutions and was followed by one in Magyaróvar in 1818. It was fifty years later - that is one and a half centuries ago - that the National Higher Institution of Agriculture opened its gates in Debrecen. The speech that opened the first academic year at the new agricultural higher school was delivered by the then director Péter Papi Balogh and it has been preserved for later generations. On 5 September 2018, a hundred and fifty years later, Dean Istvan Komlosi had the honour to recall the first 150 years of agricultural tertiary education in Debrecen. His speech is published in full length by Gerundium, the journal devoted to papers on the history of the University of Debrecen.
\end{abstract}

Tisztel Vendégeink, engedjék meg, hogy a jeles évforduló kapcsán számba vegyük mindazt, amit megőriztünk a múltból, és mindazt, amit továbbvinnünk érdemes.

Jogelődünk, a debreceni Országos Felsőbb Gazdasági Tanintézet 1868-as kapunyitásával az ország keleti felén is megindult az intézményes agrárfelsőoktatás. Elődünk később Magyar Királyi Gazdasági Akadémia néven nemzetközi hírnevet is szerzett. A felsőfokú agrároktatás történetében jelentős mérföldkő volt 1970, amikor a korábbi hároméves akadémiai, majd a négyéves főiskolai képzésből ötéves képzést nyújtó egyetemi kar fejlődött ki. Létrejött a Debreceni Agrártudományi Egyetem, amely Európaszerte elismert szakembereket adott és ad a magyar agráriumnak a Dunán innen, a Tiszántúl, és angol nyelvü képzéseink révén nem csak a magyar mezőgazdaságnak, hanem immár a Debreceni Egyetem részeként a világ számos országának. Debrecen, a kezdetektől napjainking mintegy 15000 szakemberrel gazdagította az agráriumot felsőfokon. Intézményünk az elmúlt másfél évszázadban számos változáson ment keresztül, viszont mindig arra törekedett, hogy sajátos arculatával és hagyományaival együtt a hazai mazőgazdaság tudományos fejlődését, gyarapodását szolgálja. A tisztes gyarapodást, alapítóink, Debrecen város polgárainak értékrendjét képviselje.

A debreceni agrár-felsőoktatás elért oda, hogy az intézmények rangsorában kiemelkedő helyen végez, világszinten a 200-250 legjobb hasonló profilú képzés között tartsák számon. Nemzetközi kapcsolataink hatékonyan működnek, mind az Európai Unió országaival - ezen belül különösen a Kárpát-medencei országokkal -, mind az Unión kívüliekkel, különösen a közel- és távol-keleti országokkal. Meghatározó jelentőséget tulajdonítunk a határon túli magyar nyelvű agrár-felsőoktatás fejlesztésének. Karunk képzése sokszínű. A lineáris képzés minden szintjén: a felsőoktatási szakképzésben, az 
alapképzésben, a mesterképzésben, a doktorképzésben és a szakirányú továbbképzésben is oktatunk. Az oktatás, kutatás, szaktanácsadás hármas egysége, a társadalmi szerepvállalás mindig is jellemezte intézményünket. Széleskörủ gazdasági kapcsolatrendszerünk nem csak a gyakorlati képzés feltételeit, hanem az alkalmazott kutatás keretrendszerét, csakúgy mint multidiszciplináris egyetemi környezet is biztosítja. Kihelyezett tanszékeink, Karunk gyakorlati élettel való kapcsolattartásának letéteményesei.

Elődeink jó példáját követve igyekszünk korszerü ismereteket, gyakorlatorientált tudást nyújtani a hallgatóknak, hogy a 150 éves úton haladva öregbíthessék intézményünk és a magyar mezőgazdaság jó hírét.

Mint ahogy az ember fogantatásának pillanata kódolja a jövőjét, úgy határozzák meg egy intézmény jövőjét is alapításának körülményei, a kezdetekkor végrehajtott intézkedések. Ezért a kezdeti körülményeket, a 150 év főbb stációit, a jelent és a várható jövőt kívánom kiemelni. Beszédem forrásmunkáit a debreceni agrártörténet neves krónikásainak köszönhetem.

\section{A múlt}

A mezőgazdasági ismeretátadás a XVII. századig a család, a helyi közösség privilégiuma volt. A parasztság körében meglévő nemzedéki tapasztalatok mindig nagyobb súllyal estek latba, mint az újdonság gyakorlatban még nem tapasztalt előnye. A mezőgazdasági termelékenység növelésében viszont megjelent a tudomány, ami a gazdaságokban nem állt rendelkezésre, így a XVIII. században hazánkban előbb mezőgazdasági szakoktatási, majd felsőoktatási intézmények létesültek.

A szakoktatási intézmények közül kiemelkedett Tessedik Sámuel 1779-ben Szarvason alapított gazdasági iskolája. A XVIII. század folyamán kialakult agro- és zootechnikai elméleteket, módszereket oktatták a kor legmagassabb színvonalán, a talaj, a talajművelés, és a termelékenység kölcsönös összefüggésének rendszerében. Ez az az összefüggésrendszer, amit az agrárképzésben mindig is szem előtt tartunk.

A felsőfokú oktatási intézmények közül a legnagyobb szerepet az 1797-ben Keszthelyen - Európában elsőként - alapított Georgikon játszotta, amely hosszú évtizedeken át kitűnően kezelt tangazdaságot is szervezett, miközben elsőrangúan képzett és díjazott oktatógárdával rendelkezett. Ezt az intézményt követte az 1818-ban Magyaróvárott megalapított tanintézet. Ez a két intézmény mindig is támogatta és példaként szolgált Debrecennek.

Az említett intázmények oktatógárdája, a végzett növendékek tudása, az alkalmazott tudományos eredmények elsősorban az ország nyugati felének mezőgazdasági fejlődését szolgálták. Nyílvánvalóvá vált, hogy ott, ahol a termelés technológiája kizárólag a hagyományos gyakorlatot követte, a termelékenység nem érte el a korszerủ mércéket. Ez volt a helyzet Debrecen város területén is a XIX. század első harmadában, mind a város birtokain, mind a Hajdúkerület városaiban és az iparosodás útján haladó Bihar 
megyében. Megfogalmazódott a parasztság mezőgazdasági oktatásának és a nagybírtok gazdasági fejlesztésének igénye.

Következésképpen az agrárszakképzés-, felsőoktatás csak akkor tölti be szerepét, ha a gyakorlatot meghaladó tudást nyújtja hallgatóinak. Továbbá, ha egy régióban nincs agrárfelsőoktatási intézmény, ahol a gyakorlatban alkalmazható új tudományos eredmények jönnek létre és ez nem sugárzik ki a vidékre, az a vidék, az a régió mezőgazdaságilag elmaradott.

Kik voltak Debrecenben a természettudományos alapokon álló agrárfelsőoktatás előfutárai? Itt idézek dr. Gergely Arthur, a KLTE Természettudományi Kara képviseletében Karunk 100 éves évfordulóján elhangzott beszédéből:

\begin{abstract}
„A Kossuth Lajos Tudományegyetem - Önökkel együtt - magáénak vallja a debreceni felsőoktatásnak a korábbi évszázadokra visszanyúló haladó hagyományait, polihisztorait, temészetbúvárait: Weszprémi Istvánt, Földi Jánost, meg kell említenünk Fazekas Mihályt a Református Kollégium egykori növendékét, és Diószegi Sámuelt, akik 1807-ben összegezték az első hazai tudományos botanikai rendszert. Meg kell említenünk Balásházy Jánost, akinek tudományos munkássága az 1840-es években korának legmagasabb fokú mezőgazdasági szakismereteit képviselte."
\end{abstract}

A debreceni tanintézet megszervezése, a Debreceni Kereskedelmi és Iparkamara képviselőjének javaslatára a város irányító testületének ülésén, a Községtanácsban 1856-ban fogalmazódott meg, melyet az 1857-ben azalábbi feltétellel foglalt támogató határozatba: amennyiben „... a tan nyelv magyar fog lenni... ” A király a képzés Országos Pénzalapból való támogatását is kilátásba helyezte, mely végülis $138000 \mathrm{Ft}$ ot jelentett. A város az új tanintézmény számára átadta a Bem téren lévő Lovagdát, ezen kívül Pallagon teljes birtokjoggal 400 katasztrális hold földet, tangazdasági célokra. A Helytartótanács adománylevelét gróf Zichy Nándor írta alá. A város és a környező települések több ezer nap közmunkával járultak hozzá az építkezéshez. Neves közéleti személyiségek, közöttük báró Lónyai Menyhért - az egykori bihari, beregi föispán, az akadémia alelnöke, egykori miniszterelnök - adományok révén járultak hozzá a könyvtár és a tanszéki felszerelések beszerzéséhez. Gazdálkodók gépeket juttattak az intézménynek. Mai szóhasználatban, ezt nevezzük „négyes hélixnek”. A tanintézet már kezdetben a felsőfokú oktatást és az alsófokú földműves iskolát is magába foglalta. A földműves iskola 1867-ben Pallagon, az Országos Felsőbb Gazdasági Tanintézet pedig a városban, 1868-ban kezdte el müködését. A korábbi iskolákkal szemben a debreceni tanintézetnek az adott országos jelentőséget, hogy nem társadalmi szerv vagy magánszemély alapította, hanem közéleti erőfeszítésből született, így a gazdaképzés során nemcsak a nagybírtokrendszer hanem a közép- és kisbirtokos gazdaságok követelményei is érvényre jutottak. Ezt a szellemiséget az intézmény ma is őrzi. Ez a közakarat tartja fenn ma is, ennek a közéletnek szolgálata hatja át ma is. 
1868. október 22-én a 41 hallgató és közéleti kiválóságok előtt Papi Balogh Péter igazgató nyitotta meg az első tanévet. A küldetést, a fensőbb gazdászati tanintézet célját eképpen fogalmazta meg:

„[...] a gazdasági pályára készülő ifjakat, mint leendő birtoktulajdonosokat, bérnököket, magasabb készültségű gazdatiszteket, jövő hivatásukra, időszerinti tudományos szakképzéssel, a gazdaság minden ágában, ugy az elméletnek, mint a gyakorlatnak alaposan előkészíteni."

Jelenthetem, hogy ezt a célt a 150 év alatt mindif szem előtt tartottuk!

A tantárgyak hármas tagolása, azaz a természettudományos alapismeretek, az agrár-szaktantárgyak és a közgazdasági-jogi-kereskedelmi ismeretek tagolása kezdetektől napjainkig jellemzik az oktatást.

E három tárgycsoport 25:60:15\%-os aránya a mai kor követelményeinek is megfelel.

Az Intézet Tangazdasága, mely az igazgató irányítása alatt, de önálló gazdasági egységként mủködött, az ország egyik mintagazdasága volt. A talajművelést, a növénytermesztést és az állattenyésztést magas fokon mutatta be hallgatóinak, és hasznára vált a környék gazdáinak is. Korszerü gépparkkal rendelkezett. Megindultak a kísérletek a talajművelés helyes módjának kiválasztására, a különböző növényfajták termesztési sorrendjének megválasztására, a tápanyagutánpótlásra, növényvédelemre. Mindezek a feltételek biztosították azt, hogy a végzett okleveles gazdák a Tiszántúl legkülönbözőbb természeti viszonyai között is eredményes, jövedelmező gazdálkodást folytassanak és legyenek alkalmasak annak továbbfejlesztésére.

Mindezek a kísérletek rendszerszerűen több mint 100 évvel később tartamkísérletek keretében folytatódtak és folynak ma is.

Az alapítást követő évben a tantestületi ülésen a könyvtárról az alábbi hangzott el:

„[...] az intézet tudományos köréhez tartozó jelesebb műveket magában foglaló könyvtár okvetlenül szükséges, hogy a tanárok hivatásuknak, mint a szaktudománynak terjesztői megfelelhessenek. [...] Megállni egyenlő volna a lemaradással.”

1876-ban a könyvtár 25 folyóiratából 16 idegennyelvü volt, a könyvtár folyamatos gyarapítására 1906-ban a tanszékek ellátmányát meghaladó, 2000 koronát folyósítottak.

Karunk jelenleg évente 20 millió forintot költ adatbázisokra, folyóiratokra, állománygyarapodásra.

Az intézmény vezetői közül számosan nemzetközi iskolázottsággal is bírtak. 1896-ban a tanintézet vezetését Tormay Béla állatorvos, bajorországi tanulmányokkal felvértezve vette át. Korábban keszthelyi tanárként, később az Állatgyógyintézet 
Állattenyésztési tanszékének vezetőjeként tevékenykedett, s a Magyar Tudományos Akadémia levelező tagja is lett. Tormay mind az oktatás, mind a tudomány területén kiemelkedő személyiség volt, és négyéves debreceni tevékenysége meghatározó volt a tanintézet történetében. A tanárokat a gyakorlati és elméleti felkészültségük alapján választotta ki. A gazdatiszti képesítéssel rendelkező tanárok, csak négy év gyakorlati tapasztalat és megfelelő külföldi tanulmányút után kaphattak kinevezést. A tanári karban a mezőgazdasági képzettségủek mellett megjelentek a műszaki, tudományegyetemi, állatorvosi képzettséggel rendelkezők. 1910-től, már csak olyan tanárt neveztek ki tanszékvezetőnek, aki a gazdatiszti oklevél mellett tudományegyetemi végzettséggel is rendelkezett.

Szűcs Mihály egykori igazgatónk jegyezte meg, „[...] hogy egyetlen tanár sem alkalmas magát kellö tudományos szinvonalon tartani, ha alkalom nem adatik arra, hogy más, elörehaladott és általánosan elismert intézményeket láthasson." A tanári kinevezés elött a múlt professzorai az Amerikai Egyesült Államokban, Franciaországban, Németországban, Svájcban, Ausztriában folytattak tanulmányutakat.

Az intézmény egész történetében jellemzők voltak az oktatók külföldi tanulmányútjai, amik az 1990-es évektől TEMPUS pályázati forrásokból új lendületet kaptak, ez a tantervek, eszközök megújulásával is járt. Elmondhatjuk ma is, hogy Amerikát, Franciaországot, Németországot, Hollandiát megjárt kollégáink vannak.

A tudományos utánpótlás nevelés mindenkor fő feladata volt az agrárfelsőoktatásnak. Az 1923-as tantestületi ülésen Ruffy-Varga Kálmán igazgató javasolta, hogy a gazdasági gyakornoki állásra jelentkezők szakdolgozatát bizottság vizsgálja meg, ismereteikről szóbeli vizsgát kötelesek tenni, s előadói képességeiket szabad órán kell bemutatniuk. Már ekkor megfogalmazták a mai habilitáció feltételeit.

Karunk ma kilenc MTA doktora címmel és $53 \mathrm{PhD}$-val rendelkező, valamint 24 habilitált oktatóval, kutatóval látja el feladatait. A minősítettek aránya 96\%. A tudományos utánpótlás nevelését már, az intézmény korábbi vezetőiről elnevezett Tormay és Kerpely, akkreditált szakkollégumokban elkezdjük, melyet 2002-ben, illetve 2012-ben hozott létre a Kar és a Centrum vezetése. Az 1963-ban kezdődött tudományos diákköri konferenciáink pedig, mondhatni reneszánszukat élik. Jövőre az Országos Agrártudományi Szekciót mi szervezzük.

A debreceni diákok tandíjmentesek voltak, a Debrecenen kívüliek tanulmányi eredménytől függő ösztöndíjban részesültek. Az ösztöndíj kiterjedt a külföldi tanulmányutakra is. Már 1871-ben hat növendéket küldött az intézet „külföldi intézetek látogatására”.

Ezt a lehetőséget ma az Erasmus és Campus ösztöndíjak biztosítják hallgatóinknak.

Külföldi hallgatók - például lengyelek - már az 1910-es években megjelentek az intézményben. Az 1970-es évektől számos külföldi diák, közöttük távol-keleti, közel-keleti, afrikai diák tanult az Agráron, akik a mai Stipendium Hungaricum előfutárai voltak. 
Külföldi diákjaink száma ez ősztől meghaladja a 100-at.

A hallgatói élet kezdetben a Református Kollégum rendje szerint szerveződött. Az intézet a megalakulásától kezdve támogatta az ifuúsági egyesületek szervezését, az első közülük az Iffúsági Segélyegylet már 1869-ben megalakult. Ez az Egylet tekinthető a mai Hallgatói Önkormányzat jogelődjének. A hallgatói érdekvédelmi, önkormányzati testületek mellett az 1960-as években jöttek létre az önképző, kulturális körök, mint az ezévben fennálásának 65. évfordulóját ünneplő Hortobágy Néptácegyüttes, mely számos hazai és nemzetközi díjat nyert, a Ceres színjátszó kör, a Fotókör, a Képzőművészeti Kör. Olyan továbbélő diákhagyományok alakultak ki, mint a gólyatáborok, a Felezés és a Sárgulás, a Kollégiumi Hét. Az 1907-ben alapított Debreceni Agrár Sport Egyesület, a DASE, 1957-ben szerveződött újjá. Az agráros sportéletet kitűnő testnevelő tanárok irányították - közöttük Kecskeméti János és Farkas István -, akik országos és nemzetközi sikerhez juttatták hallgatóinkat. Mindehhez a kollégium, mint második otthon biztosította és biztosítja a hátországot.

Visszatérve Tormayra, ő arra is törekedett, hogy egy oktató minél kevesebb tárgynak legyen az előadója, és minden tárgyhoz biztosítva legyen egy segédtanár. Ezt az elvet ma is igyekszünk szem előtt tartani. Ő szervezte meg a tanszékek rendjét, meterológiai állomást hozott létre, mely számos, klimatikus tanulmány alapját biztosította. Igazgatóként irányította a tanárok továbbképzését, szervezte a társadalmi munkát, a tanárok iskolán kívüli ismeretterjesztő tevékenységét. Az igazgató a tangazdaság mellett irányította a Földműves Iskolát, a magvizsgálót (ami évente 1200 mintát vizsgált, és amelyet a manapság évente 12000 mintát vizsgáló Agrárműszerközpont elődjének tekinthetünk. Tormay felügyelte továbbá a vegykisérleti állomásokat, a gazdatanácsadó testületet (mely az intézmény szaktanácsadási tevékenységének jogelődje), valamint a gazdasági egyesületek továbbképzését (mely az Agrár és Gazdálkodási Szak- és Továbbképzési Intézetünk jogelődje).

Az oktatók közül többen országos, vagy megyei szakmai tisztségeket is betöltöttek, és ez így van ma is. A kezdetekről megemlíthetjük Szűcs Mihályt, aki a Debreceni Gazdasági Egyesület titkára volt, Váczi János pedig az elnöke. Kerpely Kálmán és Sporzon Pál, a Köztelek rovatvezetői is voltak, Kerpely közel 40, Sporzon 20 évig.

Ma pedig az agrárium vonatkozásában megemlíthetjük Mihók Sándort a Magyar Állattenyésztők Szövetségének alelnökét, Jávor Andrást a Juh Terméktanács elnökét, Apáti Ferencet a Fruitveb alelnökét.

Az intézmény az 1888. évi brüsszeli kiállításon gyapjúval, az 1890-es bécsi kiállításon több állat- és növényfajtával, az 1894-es szentpétervárin (bronzzal kitüntetve) gyümölcsökkel vett részt, a párizsi kiállításon pedig aranyéremmel tüntették ki. A Rómában működő Nemzetközi Mezőgazdasági Intézet szaklevelezői hálózatába az intézmény 1912-ben kapcsolódott be. 1913-ban az amerikai Cukorrépatermesztők Szövetségének titkára, a washingtoni Truman G. Palmer debreceni szaktanácsot kért a cukorrépatermesztés talajviszonyairól. 
Debrecen története folyamán számos nemzetközi és hazai konferenciát szervezett. Csak a közelmúltbelieket említve a Nagyüzemi Juhtenyésztésit 1984-ben, az Európai Gyepgazdálkodási Szövetség Konferenciáját 1998-ban, az Európai Agronómiai Kongresszust a 2014-ben, Talajtani Vándorgyülést 2016-ban.

A hazai és nemzetközi kutatási eredmények közlésére az 1966-ban alapított Agrártudományi Közlemények, a megújult Acta Agraria Debreceniensis nyújt további lehetőséget. A Nagyváradi Egyetemmel közösen szerkesztett folyóiratunk a Natural Resources and Sustainable Development.

Az intézménynek kezdetektől jelentős volt a társadalmi szerepvállalása is. A néptanítóknak nagy szerepük volt a vidéki lakosság gazdasági ismereteinek bővítésében is. A debreceni tanintézet javaslatára a Minisztérium 1870-ben rendeletet adott ki a néptanítók továbbképzéséről. Az intézet nekik szóló tanfolyamai kéthónaposak, ingyenesek voltak. 1870 és 1907 között 1280 néptanítót képeztek ki. Már 1871-től kezdve népszerüsítő tudományos és gazdaképző előadásokat tartottak az intézmény oktatói, felhasználva a Gazdasági Egylet, a Polgári Kör, az Országos Magyar Gazdasági Egyesület lehetőségeit. A debreceni oktatóknak Szolnok, Temesvár és Zombor sem volt távol, hogy előadásaikat megtartsák.

Ma Nagyváradon és Kisvárdán kihelyezett képzés keretében folynak az előadások, de ezen rendezvények mai utódaiként említhetjük a Búza, Kukorica, Repce Tanácskozásokat, a Tiszántúli Növényvédelmi Fórumot is.

Nem lebecsülendő az a segítség, amelyet a tanintézet a paraszti mintagazdaságok kialakítása érdekében tett. Feladata volt a talajvizsgálat, a minőségi termékek kiválasztása és az általános felvilágosítás. 1901-ben Géres községben például Bartha János gazdálkodó gazdaságából ezen segítség révén lett mintagazdaság.

Az 1960-as, 70’es években intézményünk szövetkezetek gazdálkodási terveit dolgozta ki, meliorációs, öntözési terveket készített. A szakmérnöki képzés 1961-ben indult meg, s a több tucat képzés közül példaként említem meg, a juhtenyésztési, takarmánygazdálkodási, halászati, öntözési, növényvédelmi képzéseket.

A vállalkozások továbbfejlesztése, versenyképességnövelése ma is központi feladatunk. A Gazdasági és Innovációs Operatív Programok keretében 14 közepes és nagyvállalattal folytatjuk kutatásainkat, 18 további vállalkozásnak pedig kutatási szolgáltatást nyújtunk.

Szintén a kezdetek kapcsán kell megemlítenünk, hogy a diákoktól az elméleti oktatás előtt egyéves szakmai gyakorlatot követeltek meg, ami megalapozta a debreceni mezőgazdasági felsőoktatás gyakorlatias jellegét.

Mindezt a mai napig fenntartjuk a hetesi- a terepgyakorlatok, az évközi és hetedik féléves gyakorlatok keretében, melyet közel 700, szerződéssel alátámasztott vállallati partnerünknél tölthetik a hallgatók. Duális képzésre pedig 14 vállalattal kötöttünk szerződést. 
A diákok felvételi vizsgája mennyiségtanból, mértanból, fizikából, természetrajzból, növénytanból, ásványtanból, kémiából jelezte a képzés természettudományos profilját, melyre története folyamán a tanári testület mindig féltve vigyázott. Teszi ezt mai is.

Az oktatás tartalmi kérdéseiben, módszertanban, gyakorlati képzésében már a kezdetektől jó kapcsolat alakult ki Keszthely, Magyaróvár és Debrecen között. Kölcsönösen tájékoztatták egymást a tantárgyfelosztásról, órarendekről, programokról. Résztvettek egymás rendezvényein, konferenciáin. Tanulmányi kirándulásokat szerveztek. Az a jó kapcsolat a további intézmények létesülésével kiterjedt Gödöllo”, Budapest, Kaposvár, Szeged és a többi agrárintézmény irányába is.

Szinte nincs olyan agrárfelsőoktatási intézmény melyikkel oktatási vagy tudományos együttmüködés ne lett volna, ne lenne. Közel hat évtizedes kapcsolat köt össze bennünket a rostocki, a nyitrai, az újvidéki, nagyváradi, eszéki egyetemekkel. A maribori, lousianai kapcsolataink új dimenziót adnak fejlődésünknek.

Oktatók vonatkozásában, Tormay Béla, ifj. Sporzon Pál, Csukás Zoltán, Bencsik István, Vinczeffy Imre, Veress László, Bocz Ernő, Popp József, Babinszky László, Kovács András és Rátky József példáin is látjuk, hogy az agrárfelsősoktatási intézmények között, és az agrárintézmények, valamint az államigazgatás között mindig jelen volt egy egészséges szakemberáramlás. A 150 éves története alatt nem volt olyan hazai agrárfelsőoktatási intézmény, amelyikkel ne lett volna valamilyen szintű kapcsolata a Karnak.

\section{Helyszinek és szervezeti keretek}

A tanintézet iránti hallgatói érdeklődés növekedése és a tanszéki felszerelések helyigénye miatt a Bem téri épület csakhamar szüknek bizonyult. 1883-ban a Református Egyház átadta a Fűvészkerti épületet, ahonnan kikötözve és új létesítményekkel bővülve, intézményünk Pallagon folytatta működését 1901-től 1949-ig. Az 1953-ban újraindított Debreceni Mezőgazdasági Akadémia a Böszörményi úton nyert elhelyezést. Bencsik István igazgató, majd rektor irányításával ekkor épültek fel mindazok a létesítmények, melyek a mögöttünk levő út ezen az oldalán találhatók. Ezt az új tanulmányi épületet ezzel az aulával a 60-as évek elején vehette birtokba az intézmény. 1953-ban az akadémia 1400 kataszteri hold területű tangazdasággal rendelkezett, ami korszerű mezőgazdasági nagyüzemmé vált. Az akadémia 1962-től Debreceni Agrártudományi Főiskolaként folytathatta működését, melyhez az 1970-es években Szarvas, Mezőtúr, Karcag és Hódmezővásárhely csatlakozott létrehozva így a Debreceni Agrártudományi Egyetemet.

Az 1950-es években az intézmény különös figyelmet szentelt az új oktatásmódszertani fejlesztésekre. A tanácsüléseken napirenden voltak a tanszéki oktatási beszámolók. Bemutató előadásokat és gyakorlatokat tartottak, melyeket aztán kielemeztek. Kitértek 
a szemléltető eszközök használatára, az előadás és gyakorlat logikai, esztétikai, nyelvi felépítésére, a hallgatóság előképzettségére, az elsajátított képességekre. Működött egy Módszertani Bizottság. A '60-as években ilyen kérdések voltak napirenden, mint a „a hallgatóság önállóságra nevelése," „a folyamatos tanulás módszerei," „az audiovizuális módszerek alkalmazása".

Ezek ma is napirenden lévő kérdések, a folyamatos fejlesztést előbb TÁMOP, ma EFOP pályázataink támogatják.

A tanári kar a tanintézet keretében folyó munkálkodáon kívül az alföldi gazdatársadalom számára is hasznos tevékenységet fejtett ki. Segítette többek között a Tiszántúli Mezögazdasági Kamara és a Debreceni Gazdasági Egyesület munkáját. Az intézmény kiemelkedő oktatói állandó szerzői voltak a Köztelek és egyéb jó hírnévnek örvendő mezőgazdasági szaklapoknak, és tisztségeket nyertek el az OMGE vezetőségében.

Örömmel jelenthetjük, hogy ma sincs ez másképp! Számos országos szakmai testület vezetőségében jelen vannak munkatársaink, a Nemzeti Agrárgazdasági Kamarával, Hajdú-Bihar Megyei szervezetével jó kapcsolatokat ápolunk, írásaink országos, nemzetközi szaklapokban megjelennek, mely nagyban hozzájárul a QS University Ranking 200-250. helyezésünkhöz.

Az egységes debreceni felsőoktatás már az Egyetem 1912-es alapításakor felmerült és mindig is felszínen volt, mígnem - az 1990-es évektől több stáción áthaladva - 2000-ben realizálódott. Az Agrártudományi Egyetem komoly szerepet vállalt a Debreceni Egyetem létrejöttében. Oktatóink vezető tisztségeket töltöttek be az előkészítő testületekben. Itt sorolom Tóth József, Kozma András, Loch Jakab, Szász Gábor, Csizmazia Zoltán korábbi rektorainkat, Nemessályi Zsolt, Győri Zoltán professzor urakat. Karunk Nagy János professzor úr személyében két ciklusban rektort és rektorhelyettest, Jávor profeszszor úr személyében három cikluson keresztül rektorhelyettest adott az Egyetemnek. 2000-től közel annyi változás történt a karon, mondhatni, mint a megelőző évtizedekben összesen. A szervezeti változásokat tekintve a gazdaságtudományi tanszékekből létrejött az Agrárgazdasági és Vidékfejlesztési Intézet majd a mai Gazdaságtudományi Kar.

Az eredményeink alapján a 2000-2010 közötti időszakot a debreceni agrár-felsőoktatás egyik kiemelkedő korszakaként tarthatjuk számon. Az Agrártudományi Centrum egységei a szellemi erők és a kutatási lehetőségek jobb kihasználásával szorosan együttműködtek az öt tudományos ernyőprogram sikeres megvalósításában. Az EU 7. keretprogramja sikeres páláyzataink sorát támogatta.

A képzési szerkezetben az egyszakos ötéves agrármérmök képzést felváltotta a lineáris képzés, szakjaink száma megtizenötszöröződött, hallgatói létszámunk megháromszorozódott. Angol nyelvű képzéseket vezettünk be, közben oktatói létszámunk harmadával csökkent. A 17 vállalati-intézményi kihelyezett tanszék, melyek száma ma további kettővel nő, segíti oktatási, kutatási tevékenységünket a tiszteletbeli docensekkel, a címzetes egyetemi tanárokkal, a díszdoktorokkal egyetemben. Doktori iskolákat működtetünk. Doktori iskoláink olyan tudományos iskolákra épülhettek, mint 
a Kerpely-Arany-Mándy-Gulyás-Bocz-Loch-Pepó nevével fémjelzett talajtani-kémiainövénytermesztési-növényvédelmi iskola, a Tormay-Csukás-Rácz-Anghi-MunkácsiHerold-Veress-Vinczeffy-Kiss örökségét őrző állatenyésztési-gyeptermesztési iskola, a Széll-Vedrődi-Pekár-Tóth-Győri-Kovács tevékenységét folytató élelmiszertudományi iskola. Itt kell megemlítenem a debreceni üzemtani iskolát is, mely a Szűts-JuhosKesztyűs-Gönczi-Kádár-Vadász-Pfau-Nemessályi-Ertsei-Nábrádi nevével fémjelzett.

A 2000-es évektől nemzetközi kapcsolataink és nemzetközi kutatási pályázataink száma kiemelten fejlődött, melyben nagy szerepe volt az egyetemi környezet katalizáló hatásának. A Debreceni Egyetem lehetőségeit kihasználva orvostudományi-természettudományi-műszaki tudományi-bölcsészettudományi együttműködésekkel bővülhettek szakjaink, kutatási tevékenységünk.

Az utóbbi években jelentős kutatási infrastruktúrával gazdagodunk, fejlesztéseinket az élelmiszerlánc mentén valósítjuk meg, s a „viz-, energiatakarékos, környezetbarát, biztonságos és gazdaságos élelmiszerelóallitás kutatása és oktatása" az a jövőkép, melynek megvalósítása érdekében végezzük tevékenységünket.

\section{Milyen jövöre készülünk?}

Az agrárfelsőoktatásban is az egyénre szabott precíziós oktatásé lesz a jövő. Célunk, hogy a naprakész, szintetizált oktatási anyagot a hallgató és a magát továbbképezni vágyó érdeklődő digitálisan bárhonnan elérhesse, illetve ha szüksége van rá, egyéni konzultációt kérhessen, az önálló és vezetett készségfejlesztést a társadalmilag és anyagilag legmagasabb szinten megbecsült oktatóktól és az infrastrukturálisan lehető legjobban felszerelt központokban kapja meg. Ezek az oktató-kutató központok a társadalmi és gazdasági szervezetek által megfogalmazott és közvetlenül támogatott forrásokból kutatási feladatokat is ellátnak. A mezőgazdaság előtt álló főbb kutatási témák a víz-, energiatakarékos, környezetbarát, biztonságos, gazdaságos, nyomonkövetett élelmiszerelőállítás és posztharveszt. Ehhez precíziós-, informatikai- és bio- technológiákat fogunk alkalmazni.

Az Agrár azért tart ma itt, mert voltak vezetői, akik mertek nagyot gondolni és nagyot alkotni.

Beszédemet dr. Csaba Béla, a Debreceni Orvostudományi Egyetem egykori rektorhelyettesének Karunk 100 éves évfordulóján elhangzott mondatával zárom: „[...] mennél jobban telnek fölötte az évek, annál fiatalabbá, életerösebbé és szebbé válik nemcsak külsö megjelenésében, hanem szellemében, alkotásában, tettvágyában."

VIVAT, CRESCAT, FLOREAT! 